\title{
PENANAMAN NILAI-NILAI PENDIDIKAN ISLAM DALAM PEMBINAAN KARAKTER PESERTA DIDIK
}

\section{IMPLEMENTING ISLAMIC EDUCATION VALUES IN DEVELOPING STUDENTS'S CHARACTERS}

\author{
A. Marjuni \\ Fakultas Tarbiyah dan Keguruan Universitas Islam Negeri Alauddin Makassar \\ h.marjunij@yahoo.com
}

\begin{abstract}
Abstrak
Tujuan dari tulisan ini adalah untuk mengetahui hakikat penanaman nilai-nilai pendidikan Islam dan upaya mewujudkan nilai-nilai pendidikan Islam pada pembinaan karakter peserta didik. Jenis penelitian yang digunakan adalah penelitian pustaka dengan pendekatan penelitian kualitatif. Data-data kepustakaan yang digunakan adalah buku-buku, catatan maupun artikel atau penelitian-penelitian terdahulu. Kumpulan konsep tersebut kemudian dianalisis untuk kemudian diperoleh hakikat penanaman nilai pendidikan Islam dalam pembentukan karakter dan upaya mewujudkan penanaman nilai-nilai pendidikan islam pada pembinaan karakter peserta didik. Hasil menunjukkan bahwa hakikat pendidikan islam dan pembinaan karakter akan membawa manusia untuk senantiasa beritikad baik dalam mengembangkan ilmu dan mewujudkan aspek kepentingan manusia dalam aktivitasnya. Melalui pendidikan Islam, kesadaran pribadi peserta didik akan timbul sebagai seorang muslim yang memiliki tanggung jawab terhadap diri sendiri, masyarakat, dan umat. Selain itu, pendidikan karakter membuat peserta didik mempunyai integritas pribadi yang tangguh, bijaksana serta dapat menghindari adanya sikap mental nihilisme, hedonisme, dan alienasi intelektual.
\end{abstract}

Kata Kunci: nilai, pendidikan Islam, karakter

\begin{abstract}
The purpose of this paper is to find out the essence of implementation the values of Islamic education and efforts to realize the values of Islamic education in fostering the character of students. This type of research is literature research with a qualitative research approach. The library data used are books, notes and articles or previous studies. The collection of concepts is then analyzed to then obtain the essence of planting the value of Islamic education in character building and efforts to realize the cultivation of Islamic educational values in the character building of students. The results show that the nature of Islamic education and character building will bring people to always have good intentions in developing knowledge and realizing aspects of human interests in their activities. Through Islamic education, students' personal awareness will arise as a Muslim who has responsibility for himself, society, and the ummah. In addition, character education makes students have strong personal integrity, wise, and can avoid the mental attitude of nihilism, hedonism, and intellectual alienation.
\end{abstract}

Keywords: value, Islamic education, character

How to Cite: Marjuni, A. (2020). Penanaman nilai-nilai pendidikan islam dalam pembinaan karakter peserta didik. Al asma: journal of Islamic Education, 2(2), 210-223. 


\section{PENDAHULUAN}

Pendidikan Islam masih diyakini sebagai perantara terbaik dalam pembentukan karakter peserta didik di masa depan dan sekaligus menjadi instrumen guna menyelamatkan gerak maju sebuah bangsa. Saat ini, perilaku terpuji dan berkarakter bukan sikap yang menjadi jaminan akan lahir melalui pendidikan. Undang-Undang Republik Indonesia Nomor 20 Tahun 2003 tentang Sistem Pendidikan Nasional menyatakan secara tegas bahwa pendidikan bertujuan untuk berkembangnya potensi peserta didik agar menjadi manusia yang beriman dan bertakwa kepada Tuhan Yang Maha Esa, berakhlak yang mulia, sehat, berilmu, cakap, kreatif, mandiri dan menjadi warga yang demokratis serta bertanggung jawab (Undang-Undang tentang Sistem Pendidikan Nasional, 2003).

Dalam pendidikan di Indonesia saat ini, aspek kognitif atau aspek intelektual menjadi aspek yang dikedepankan dalam dunia pendidikan. Aspek kognitif atau aspek intelektual merupakan aspek yang mengedepankan pengembangan pengetahuan, pemahaman serta keterampilan berpikir. Tujuan pengembangan ilmu pengetahun di negara berkembang salah satunya ialah mengejar ketertinggalan dengan negara yang telah maju. Tujuan tersebut dapat tercapai melalui lembaga pendidikan. Melalui lembaga pendidikan, akan lahir generasi yang pandai dalam teori, kuat dalam menghafal, mahir dalam menyelesaikan persoalan, dan akan menjadi selembaran kertas yang menunjukkan kemampuan seseorang selama menempuh pendidikan (Siradj, 2006). Namun, pendidikan saat ini tidak menjamin lahirnya manusia-manusia yang baik moralnya, kuat imannya, dan berkarakter, serta siap menghadapi tantangan, displin, jujur, bertanggungjawab dan lain sebagainya.

Konsep pendidikan Islam secara normatif sarat dengan nilai-nilai transendental Ilahiyah dan Insaniah. Nilai-nilai tersebut terbingkai dalam bingkai besar yaitu humanisme teosentris. Konsep atau teori humanisme teosentris merupakan teori pendidikan yang berorientasi pada aksi (action) untuk dapat melihat dampak sosialnya. Untuk menekankan perlunya aksi, nilai-nilai karakter yang humanis teosentris itu diangkat sebagai paradigma ideologi pendidikan Islam (Achmadi, 2010).

Dalam penanaman nilai-nilai pendidikan Islam terdapat tiga tujuan yang ingin dicapai, yaitu (a) menyiapkan generasi muda dalam mengambil peran di masyarakat pada masa yang akan datang, (b) mentransfer ilmu pengetahuan berdasarkan peran yang diharapkan di masa mendatang, dan (c) mentransfer nilai-nilai dan budaya untuk mendukung membentuk karakter dalam rangka memelihara keutuhan dan kesatuan masyarakat sebagai prasyarat bagi kelangsungan hidup masyarakat dan peradaban (Langgulung, 1980; Usa, 2001). Ketiga tujuan tersebut, dapat dilihat pada tujuan kedua dan keempat menunjukkan bawa pendidikan tidak hanya untuk transfer ilmu pengetahuan, tetapi juga sekaligus mewujudkan transfer nilai.

Fenomena empirik saat ini menunjukkan bahwa terdapat banyak kasus yang menunjukkan bahwa saat ini banyak remaja yang terlibat dalam kasus kenakalan remaja. Kasus-kasus tersebut berupa perkelahian antar pelajar, premanisme, mengonsumsi alkohol, etika berlalu lintas, tindak kekerasan, kriminalitas yang semakin tinggi dan semakin rumit dan sebagainya. Kasus-kasus tersebut dapat dilihat di berbagai media, baik online maupun offline yang mengindikasikan bahwa pendidikan moral pada anak belum maksimal. Timbulnya kasus-kasus tersebut memang tidak semata-mata karena kegagalan pendidikan akhlak dan pendidikan karakter di sekolah yang lebih menekankan aspek 
kognitif, tetapi juga bagaimana semua kasus tersebut dapat mendorong serta menggerakkan guru untuk mencermati kembali dan mencari solusi melalui pengembangan pembelajaran pendidikan agama Islam yang berorientasi pada pembinaan nilai-nilai karakter. Sebagaimana penelitian yang dilakukan oleh (Andriato, 2019) bahwa upaya yang dilakukan untuk mengatasi kenakalan remaja diantaranya remaja diberi pencerahan, pengarahan Agama, harus ada kajian pendidikan Agama, lebih tingkatkan pengajian dan majelis taklim. Oleh karena itu, perlu mengetahui lebih jauh tentang hakikat penanaman nilai pendidikan Islam dalam pembentukan karakter dan upaya mewujudkan penanaman nilai-nilai pendidikan islam pada pembinaan karakter peserta didik.

\section{METODE PENELITIAN}

Metode dalam penelitian ini adalah penelitian pustaka (library research) dengan menggunakan pendekatan penelitian kualitatif. Penulis dalam hal ini berupaya mengumpulkan data-data kepustakaan baik melalui buku-buku, catatan maupun artikel atau penelitian-penelitian terdahulu. Kumpulan konsep tersebut kemudian dianalisis untuk kemudian diperoleh hakikat penanaman nilai pendidikan Islam dalam pembentukan karakter dan upaya mewujudkan penanaman nilai-nilai pendidikan islam pada pembinaan karakter peserta didik.

\section{HASIL DAN PEMBAHASAN}

\section{Hakikat Penanaman Nilai Pendidikan Islam dalam Pembentukan Karakter}

Konsep tentang nilai-nilai pendidikan Islam secara kuantitatif yaitu usaha yang dilakukan untuk menjadikan pendidikan Islam memberikan pengaruh lebih besar, merata, dan meluas dalam dunia pendidikan pada umumnya. Sedangkan secara kualitatif, usaha menjadikan pendidikan Islam lebih baik, bermutu, dan lebih maju dengan tetap memperhatikan ide-ide dasar atau nilai-nilai Islam yang memang seharusnya selalu berada di depan dalam merespon dan mengantisipasi berbagai tantangan yang dihadapi dalam dunia pendidikan. Selain itu, dalam pengertian kualitatif pendidikan Islam adalah usaha yang dilakukan dalam mengembangkan pendidikan Islam agar dapat berkontribusi secara signifikan dalam pembangunan masyarakat dan pengembangan iptek melalui pembangunan keilmuan yang kokoh (Muhaimin, 2008).

Istilah nilai adalah sesuatu yang bersifat abstrak, ia sifatnya ideal, nilai bukan konkrit, bukan fakta. Tidak hanya persoalan benar dan salah yang menuntut pembuktian secara empirik, melainkan penghayatan yang dikehendaki dan tidak dikehendaki, dan juga merupakan suatu sifat yang melekat pada sesuatu (sistem kepercayaan) yang telah berhubungan dengan subjek yang memberi suatu arti (manusia yang meyakini) (Thoha, 1996). Nilai merupakan sesuatu yang bermanfaat dan berguna bagi manusia sebagai acuan tingkah laku yang merupakan sifat-sifat (hal-hal) penting atau berguna bagi kemanusiaan dan dapat menyempurnakan manusia sesuai dengan hakikatnya. Jadi, penanaman nilai adalah suatu tindakan yang dilakukan dengan persiapan yang matang dan detail mengenai persoalan yang bersifat abstrak yang berguna dan bermanfaat sebagai acuan atau dasar dalam bertingkah laku bagi manusia.

Muhaimin mengemukakan bahwa penanaman nilai-nilai pendidikan Islam dapat mengandung berbagai makna yaitu upaya yang dilakukan dalam mengembangkan 
pendidikan Islam agar dapat berkontribusi secara signifikan dalam pembangunan masyarakat dan pengembangan ilmu pengetahuan. Selain itu, juga usaha dalam pengembangan model-model pendidikan Islam yang lebih inovatif dan kreatif, dengan tetap berkomitmen terhadap dimensi-dimensi fondasionalnya sebagai landasan pijak dalam mengembangkan pendidikan Islam (Muhaimin, 2011).

Azyumardi Azra mengemukakan bahwa dalam penanaman nilai-nilai pendidikan Islam, individu diajak untuk berpikir kreatif, analisis-kritis, dan inovatif tentang berbagai praktik dan isu pendidikan yang sedang dihadapi untuk dikaji dan menjadi bahan untuk ditelaah dari dimensi fondasionalnya agar tidak kehilangan roh atau spirit Islam yaitu memperkaya nuansa pemikiran dan teori-teori yang telah ada atau menciptakan pemikiran atau teori baru tentang pendidikan yang belum ada sebelumnya (Azra, 2006). Una Kartawisastra mengemukakan pengertian nilai adalah suatu tipe kepercayaan yang berada dalam ruang lingkup sistem kepercayaan, dimana individu tersebut bertindak atau menghindari suatu tindakan, atau tentang sesuatu yag pantas atau tidak pantas untuk dilakukan, dipercayai, dan dimiliki (Kartawisastra, 1980). Nilai merupakan preferensi yang dapat dilihat melalui perilaku seseorang sehingga setiap tindakan atau perilaku yang dilakukan akan menunjukkan nilai yang dipegangnya. Jadi, nilai adalah sikap, konsep dan keyakinan yang dipandang berharga oleh individu. Jika "nilai" dikaitkan dengan "agama" maka ia dikenal dengan "nilai religi" atau disebut juga "nilai keagamaan" maka pengertianya adalah tingkatan integritas kepribadian yang mencapai tingkat budi yang bersifat mutlak kebenaranya, universal dan sesuai (Syam, 1986). Nilai religi atau nilai keagamaan tersebut dapat diberikan melalui pendidikan. Hal ini dikarenakan salah satu fungsi pendidikan adalah mentransmisikan nilai-nilai. Dalam konteks pendidikan Islam nilai-nilai tersebut yang ditransmisikan adalah nilai-nilai Islam. Nilai-nilai sering diartikan sebagai prinsip, standar atau kualitas yang dipandang bermanfaat dan sangat diperlukan (Poerwadarminta, 2003). Sedangkan menurut Muhaimin nilai-nilai adalah "suatu keyakinan dan kepercayaan yang menjadi dasar bagi seseorang atau sekelompok orang untuk memilih tindakannya, atau menilai suatu yang bermakna bagi kehidupannya (Muhaimin, 2009).

Pendidikan Islam di sini tidak hanya dipahami sebatas "ciri khas" jenis pendidikan yang berlatar belakang keagamaan. Tetapi, pendidikan Islam menurut Zarkawi Soejoeti, berarti: pertama, jenis pendidikan yang pendirian dan pelaksanaannya didorong oleh hasrat dan cita-cita untuk mewujudkan nilai-nilai Islam, baik yang nampak melalui nama lembaganya maupun melalui kegiatan-kegiatan yang dilaksanakan di lembaga tersebut. Dalam hal ini, Islam ditempatkan sebagai sumber nilai. Kedua, jenis pendidikan yang memperhatikan dan sekaligus menjadikan ajaran Islam sebagai mata pelajaran, bidang studi, sebagai ilmu yang diperlakukan sama dengan ilmu lainnya. Ketiga, jenis pendidikan yang mencakup kedua hal tersebut. Dalam hal tersebut, Islam merupakan sumber nilai dan sebagai bidang studi yang diajarkan melalui program yang diselenggarakannya (Fadjar, 1993).

Pendidikan Islam merupakan sebuah proses yang memerlukan sistem dan sasaran yang hendak dicapai berdasarkan sistem tersebut. Sasaran atau tujuan penting dalam program pendidikan, dengan adanya tujuan maka dapat diketahui arah atau tujuan yang akan dicapai. Jika tidak ada tujuan yang jelas dalam penyelenggaraannya maka arahnya tidak memiliki ketentuan sehingga dalam prosesnya akan menghilangkan nilai hakiki pendidikan. Bahkan dapat menafikan harkat dan martabat serta nilai-nilai kemanusiaan 
sebagai khalifah Allah di muka bumi yang menegaskan aspek dan kemampuan individual dan sosial serta moral merupakan hakikat kemanusiaan (Arifin, 1991).

Oleh karena itu, adanya tujuan dalam proses pendidikan merupakan keharusan yang hendak dicapai yang telah dirumuskan dengan baik akan mengarahkan proses pendidikan Islam menuju pengembangan individu dengan optimal pada tiga aspek kemampuan dengan tetap berdasar pada nilai-nilai dan ajaran Islam (Azra, 2006).

Pendidikan yang saat ini berkembang pesat tidak hanya melahirkan generasi yang membawa perubahan tetapi juga berefek samping dengan melahirkan banyaknya koruptor. Meskipun tidak semuanya adalah koruptor dan teroris, umumnya para pelaku koruptor merupakan orang dengan berbagai gelar yang menunjukkan tingkat pendidikan mereka. Hal ini menunjukkan adanya kesalahan dalam pendidikan di Indonesia (Siradj, 2006).

Adapun Istilah karakter berasal dari bahasa Yunani karakter yang berakar dari diksi "karasso" atau "charassein" yang berarti memahat atau mengukir, sedangkan dalam bahasa latin karakter bermakna membedakan tanda bahasa Indonesia (Munir, 2010), karakter di dalam bahasa Indonesia dapat diartikan sebagai sifat kejiwaan/tabiat/watak (Nawanti, 2012; Zubaedi, 2012). Karakter dalam bahasa Inggris ditulis character, secara psikologis dapat dimaknai sebagai kepribadian seseorang yang ditinjau berdasar etis atau moral, seperti kejujuran seseorang biasanya mempunyai kaitan dengan sifat-sifat yang relatif tetap (Kartono \& Gulo, 1987). Karakter di dalam Kamus Besar Bahasa Indonesia berarti sifat-sifat kejiwaan, akhlak atau budi pekerti yang membedakan seseorang dengan yang lain, tabiat, dan watak, dengan demikian, karakter merupakan kualitas mental, moral, akhlak, dan budi pekerti seseorang yang membedakannya dengan orang lain. Salah satu tokoh pendidik, G.W. Allport yang dikutip oleh Sri Narwanti memberikan defenisi bahwa karakter merupakan suatu organisasi yang dinamis dari sistem psiko-fisik individu yang menentukan tingkah laku dan pemikiran individu secara khas dan mengarahkan pada tingkah laku manusia (Nawanti, 2012).

Karakter bukan sekedar sebuah kepribadian (personality) tetapi karakter merupakan kepribadian yang ternilai (Nawanti, 2012). Kepribadian menjadi ciri khas, gaya, karakteristik, dan sifat khas dalam diri seseorang yang dibentuk berdasarkan apa yang diterima dari lingkungannya, misalnya lingkungan keluarga sejak kecil dan bawaannya sejak lahir (Koesoema, 2007). Diibaratkan sebagai kehidupan, karakter merupakan blok granit yang dirancang dan dipahat dengan sangat hati-hati dan tidak dipukul secara sembarangan yang pada akhirnya akan menjadi sebuah mahakarya yang dapat menjadikan puing-puing rusak. Oleh karena itu, karakter orientasinya ke kualitas mental atau moral, kekuatan moral, nama atau reputasi (Hidayatullah, 2014).

Selain itu, pengertian karakter juga dilontarkan oleh Abdullah Munir dengan makna penggambaran secara implisit maupun eksplisit tingkah laku seseorang dengan melalui penampilan nilai (benar-salah, baik-buruk) (Munir, 2010). Kemudian Muthahharah sebagaimana dikutip oleh Lanny Oktavia mengatakan bahwa karakter adalah individu yang sesungguhnya, erat kaitannya dengan siapa anda sesungguhnya. Hal ini menunjukkan kepada kegunaan dan keunggulan satu produk manusia (Octavia dkk., 2014). Dengan demikian karakter yang dimaksudkan adalah sikap yang sabar, rendah hati, jujur, sopan dan tulus ikhlas dalam pergaulan. Dalam bukunya Masnur Muslich mengutip berbagai tokoh yang berpendapat mengenai makna karakter, seperti Simon Philips memberikan defenisi karakter adalah kumpulan tata nilai yang menuju pada suatu sistem yang melandasi 
pemikiran, sikap dan perilaku yang ditampilkan. Begitu pula, Koesoema menyatakan bahwa karakter sama dengan kepribadian. Kepribadian dianggap sebagai "ciri atau karakteristik, gaya, sifat khas dari diri seseorang yang bersumber dari bentukan-bentukan yang dari lingkungan sekitar dan juga bawaan sejak lahir. Sedangkan Suyanto (2015) menyatakan bahwa karakter adalah cara berpikir dan berperilaku yang menjadi ciri khas tiap individu untuk hidup dan bekerjasama, baik dalam lingkup keluarga, masyarakat, bangsa dan negara. Tak lupa pula, Masnur Muslich mengutip Imam Ghazali mengatakan bahwa karakter itu lebih dekat dengan akhlak, yaitu spontanitas manusia dalam bersikap, atau perbuatan yang telah menyatu dalam diri manusia sehingga ketika muncul tidak perlu dipikirkan lagi (Muslich, 2013).

Dapat disimpulkan bahwa karakter itu berkaitan dengan kekuatan moral yang positif, dan bukan konotasi negatif. Individu atau orang berkarakter adalah orang yang mempunyai kualitas moral yang positif. Karakter adalah suatu hal yang unik hanya ada pada individual atau pun pada suatu kelompok, bangsa. Karakter merupakan landasan dari kesadaran budaya, kecerdasan budaya dan merupakan pula perekat budaya. Sedangkan nilai dari sebuah karakter digali dan dikembangkan melalui budaya masyarakat itu sendiri. Terdapat empat modal strategis yaitu sumber daya manusia, modal cultural, modal kelembagaan, serta sumber daya pengetahuan. Keempat modal tersebut penting bagi penciptaan pola pikir yang memiliki keunggulan kompetitif sebagai suatu bangsa (Nawanti, 2012).

Oleh karena itu, pendidikan karakter menurut Thomas Linckona adalah pendidikan untuk membentuk kepribadian seseorang melalui pendidikan budi pekerti, yang hasilnya terlihat dalam tindakan nyata seseorang, yaitu tingkah laku baik, jujur, bertanggungjawab, menghormati hak orang lain, kerja keras (Gunawan, 2014). Sedangkan pakar pendidikan perspektif gender, Megawangi memberikan definisi pendidikan karakter sebagai proses internalisasi budaya ke dalam diri seseorang dan masyarakat sehingga membuat orang dan masyarakat beradab (Megawangi, 2004). Pendidikan karakter dalam grand designnya merupakan proses pembudayaan dan pemberdayaan nilai-nilai luhur dalam lingkungan satuan pendidikan (sekolah), lingkungan keluarga dan lingkungan masyarakat. Menurutnya pendidikan karakter merupakan upaya yang dilakukan oleh pendidik, keluarga dalam membentuk seluruh potensi individu mulai dari kognitif, afektif dan psikomotorik dalam interaksi sosial lingkungan keluarga, sekolah dan masyarakat yang hasilnya terlihat dari tindakan seseorang dalam perbuatan dan tingkah laku.

Pendidikan karakter dan kepentingan nasional Indonesia merupakan kepentingan bangsa dan negara dalam mewujudkan cita-cita dan tujuan nasional Indonesia yang di dalamnya mencakup usaha mencerdaskan kehidupan bangsa. Lalu implementasinya apa. Rumusan mencerdasakan kehidupan bangsa itu memiliki 2 (dua) arti penting yaitu membangun manusia Indonesia yang cerdas dan berbudaya. Pengertian cerdas harus dimaknai, bukan saja sebagai kemampuan dan kapasitas untuk menguasai ilmu pengetahuan, budaya serta kepribadian yang tangguh akan tetapi juga memiliki kecerdasan emosional yang dengan bahasa umum disebut sebagai berkarakter mulia atau berbudi luhur, berakhlak mulia (Suyanto, 2015), sedangkan berbudaya memiliki makna sebagai kemampuan dan kapasitas untuk menangkap dan mengembangkan nilai-nilai moral dan kemanusiaan yang beradab dalam sikap dan tindakan berbangsa dan bernegara (karakter bangsa) dengan penuh tanggung jawab (Zubaedi, 2012). 
Gagasan ini muncul karena proses pendidikan yang selama ini dilakukan dinilai belum sepenuhnya berhasil dalam membangun menusia Indonesia yang berkarakter. Penilaian ini didasarkan pada banyaknya para lulusan sekolah dan sarjana yang cerdas secara intelektual, namun tidak bermental tangguh dan berperilaku tidak sesuai dengan tujuan mulia pendidikan (Azzet, 2011).

Kemajuan suatu bangsa terletak pada karakter yang dimiliki bangsa tersebut. Karakter merupakan hal yang sangat penting dan mendasar. Karakter adalah mustika hidup yang membedakan antara manusia dengan hewan. Manusia yang tidak berkarakter dikatakan sebagai manusia yang sudah melampaui batas. Orang yang berkarakter kuat dan baik secara individual dan sosial ialah yang memiliki akhlak, moral dan budi pekerti yang baik (Zubaedi, 2012).

Karakter positif seseorang akan mengangkat status pada derajat yang tinggi dan mulia bagi dirinya. Kemulian seseorang terletak pada karakternya. Aristoteles melihat karakter sebagai kemampuan melakukan tindakan yang baik dan bermoral, Psikolog Frank Pittman yang dikutip Zubaedi mengamati bahwa kestabilan hidup bergantung pada karakter (Zubaedi, 2012). Penjelasan tersebut mengindikasikan bahwa pembinaan karakter pada hakikatnya mengarah pada kejiwaan yang berimplikasi pada tingkah laku. Menurut ajaran Islam, pembinaan karakter kepada generasi muda sangat penting, agar tercipta generasi yang memiliki pengetahuan dengan perilaku yang baik atau Islam menyebutnya akhlaq al-karimah. Remaja diharapkan memberikan yang terbaik bagi bangsa, pendidikan dan pembinaan kepada generasi muda merupakan tanggung jawab semua lapisan masyarakat, pada lingkungan keluarga, masyarakat sosial, dan masyarakat sekolah.

Manusia sebagai makhluk yang paling sempurna juga sebagai makhluk pedagogik yang memiliki berbagai macam potensi untuk dikembangkan. Manusia sebagai makhluk yang berkembang memerlukan pendidikan untuk mengarahkan dan mengembangkan potensi yang dimilikinya ke arah yang positif. Melalui pendidikan manusia diharapkan mampu mengembangakan potensi yang dimilikinya dan memperoleh ilmu pengetahuan serta kedudukan yang lebih baik, dalam QS Al-Mujadalah/ 58 : 11 sebagai berikut.

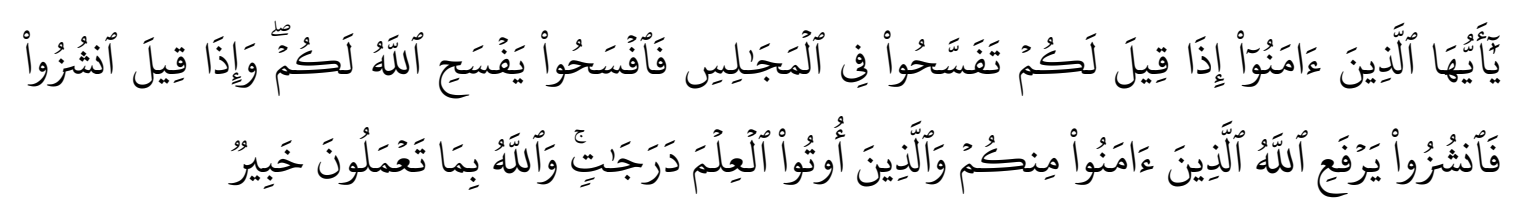

Terjemahnya:

Wahai orang-orang beriman! Apabila dikatakan kepadamu, " Berilah kelapangan di dalam majelis-majelis, " maka lapangkanlah, niscaya Allah akan memberi kelapangan untukmu. Dan apabila dikatakan, " berdirilah kamu," maka berdirilah, niscaya Allah akan mengangkat (derajat) orang-orang yang beriman diantara kamu dan orang-orang yang diberi ilmu beberapa derajat. Dan Allah Mahateliti terhadap apa yang kamu kerjakan (Kementerian Agama RI, 2003).

Ayat-ayat di atas memberikan gambaran, bahwa menutut ilmu itu sangat penting bagi manusia untuk mengembangkan potensi yang telah dianugerahkan Allah swt kepada manuasia. 
Peningkatan mutu pendidikan merupakan sasaran pembangunan di bidang pendidikan nasional dan merupakan bagian integral dari upaya peningkatan kualitas manusia Indonesia secara menyeluruh. Pemerintah dalam hal ini Menteri Pendidikan Nasional pada tanggal 2 Mei 2002 telah mencanangkan "Gerakan Peningkatan Mutu Pendidikan" dan lebih terfokus lagi, setelah diamanatkan dalam Undang-undang Republik Indonesia No. 20 Tahun 2003 Tentang Sistem Pendidikan Nasional.

Belakangan ini, pendidikan Islam dalam membina karakter masih kurang terasa, pendiidkan tidak memperhatikan keseimbangan antara intelektual dan spiritual sehingga menjadikan manusia bersifat materialis, pragmatis, dan individualis yang merupakan sikap yang tidak layak dimiliki oleh khalifah di muka bumi. Kehidupan sosial keagamaan, memberikan pendidikan yang tidak hanya menjadikan manusia menjadi sosok yang potensial pada intelektual transfer of knowledge yang kental, tetapi juga melalui proses tersebut bermuara pada upaya pembentukan peserta didik yang berkarakter, beretika, dan berestetika melalui transfer of values yang terkandung di dalamnya.

Pendidikan karakter merupakan proses yang terpadu dan komprehensif. Selain menjadikan peserta didik tetap responsif terhadap perkembangan ilmu pengetahuan dan teknologi juga dilakukan upaya untuk mempertahankan aspek normatif yang begitu jelas peranannya dalam menciptakan suatu model kehidupan sosial yang berkarakter dan humanis. Pendidikan karakter dengan sendirinya telah menempati posisi sentral dan strategis dalam membangun kehidupan sosial yang humanis yang akan menuntun manusia dalam pencapaian suatu kehidupan yang lebih baik dari generasi sebelumnya dan dari masa sebelumnya. Komitmen tersebut dibangun dalam model yang tetap menonjolkan aspek kemanusiaan, ketuhanan, yang menunjukkan nilai keluhurannya dan menguatkan keberadaannya sebagai sebaik-baik makhluk. Pendidikan akhlak merupakan pengetahuan agama yang bersifat kognitif menjadi "makna" dan "nilai karakter" yang perlu diinternalisasikan dalam diri peserta didik, untuk selanjutnya menjadi sumber motivasi bagi peserta didik untuk bergerak, berbuat dan berperilaku secara konkret agamis yang berlandaskan nilai-nilai karakter dalam kehidupan sehari-hari (Suyanto, 2015).

Pendidikan Islam dan pembinaan karakter akan membawa manusia untuk senantiasa beritikad baik dalam mengembangkan ilmu dan mewujudkan aspek kepentingan manusia dalam aktivdiitasnya. Dengan kata lain, pengembangan ilmu pengetahuan seluruhnya diperuntukkan bagi kesejahteraan manusia dan tetap menjamin kelangsungan hidupnya menurut norma-norma yang berlaku, baik berdasarkan kriteria sosial, budaya, ekonomi, politik, maupun etika kedamaian. Oleh karena itu, dalam menciptakan atau mengembangkan intelektual muslim yang berkarakter secara kualitatif, maka perlu adanya penyegaran kembali ajaran-ajaran akhlak, etika dan moral berdasarkan prinsip-prinsip Islam. Pendidikan islam hendaknya menimbulkan kesadaran pribadi peserta didik sebagai seorang muslim yang bertanggung jawab terhadap diri, masyarakat, dan umat. Pendidikan karakter membuat peserta didik mempunyai integritas pribadi yang tangguh, arif dan bijaksana serta terbuka. Karakter dapat menghindari adanya sikap mental nihilisme, hedonisme, dan alienasi intelektual (Azra, 2006). Kaum intelektual dengan kualifikasi seperti inilah yang dapat diharapkan mewujudkan kebangkitan Islam, yang pada akhirnya ia mampu menjabarkan ajaran-ajaran Islam secara sistematis, terpadu dan meyeluruh serta relevan dengan tantangan dunia modern. 


\section{Upaya Mewujudkan Penanaman Nilai-Nilai Pendidikan Islam pada Pembinaan Karakter Peserta Didik}

Nilai-nilai pendidikan Islam sangatlah penting, karena dengan demikian peserta didik dapat memfungsikan segenap potensi, dan tanggung jawabnya sebagai khalifah, membebaskan belenggu kehidupan yang bisa mengancam umat Islam dalam percaturan dunia modern. Pendidikan Islam harus mewariskan nilai-nilai kemanusiaan kepada peserta didik. Mendorong peserta didik tidak sekedar membekali dirinya untuk kepentingan individual, melainkan lebih jauh lagi agar kelak mereka dapat melakukan kegiatan-kegiatan sosial, mendarmabaktikan dirinya kepada kerja kemanusiaan, maka kedewasaan diri yang bernilaikan kemanusiaan berkarakter pada perkembangan pribadi peserta didikyang kelak dapat beradaptasi dalam setiap transisi kemajuan secara survival. Mereka mampu menemukan aspek kehidupan baru dan tetap eksis dalam menghadapi problema kehidupan (Azra, 2006). Eksistensi suatu lembaga pendidikan Islam dalam penanaman nilai-nilai Islam di tengah-tengah masyarakat tidak lain merupakan perwujudan dari kebutuhan masyarakat terhadap pendidikan. Hal itu merupakan suatu hal yang mesti ada dalam suatu komuditas masyarakat. Demikian pentingnya keberadaan lembaga pendidikan itu, sehingga secara ekstrim dapat dikatakan bahwa maju mundurnya suatu masyarakat atau bangsa sangat ditentukan oleh maju mundurnya pendidikan yang dilaksanakan oleh masyaratak atau bangsa itu (Sudirman, 2007). Sejalan dengan itu, Hasan Langgulung mengemukakan bahwa sejarah peradaban-peradaban besar yang pernah dikenal oleh sejarah menunjukkan bahwa kehancuran yang dialami oleh peradaban-peradaban besar itu adalah sebagai akibat dari kegagalan pendidikan dalam menjalankan fungsinya, dengan kata lain, pendidikan adalah suatu tindakan (action) yang diambil oleh suatu masyarakat, kebudayaan, atau peradaban untuk memelihara kelanjutan hidupnya (survival) (Langgulung, 1980). Artinya pendidikan merupakan pilihan bagi masyarakat untuk melestarikan identitasnya, di samping untuk menyiapkan generasi muda untuk dapat hidup secara layak pada masa yang akan datang.

Timbullah kesadaran di kalangan pemerhati pendidikan Islam, sebutlah Muhammad Abduh dalam buku Harun Nasution (Asmuni, 2009; Nasution, 2001). Misalnya, bahwa dengan kemajuan ilmu pengetahuan dan teknologi, ternyata telah mengantar Barat mencapai kemajuan pesat dan mendatangkan kemudahan dalam berbagai bidang kehidupan. Akan tetapi kemajuan teknologi tidak identik dengan kemajuan sosial. Teknologi telah menekan pikiran dan hati manusia (sombong, congkak dan semena-mena) yang menggunakannya. Pikiran manusia telah dikontrol oleh teknologi dalam arti dikuasai oleh cara berfikir dan nilai-nilai yang dijunjung tinggi oleh pencipta teknologi.

Kesadaran tersebut lalu mengkristal sebagai kebutuhan mendesak, timbullah gagasan dan usaha-usaha untuk merekonstruksi lembaga pendidikan Islam agar relevan dengan kebutuhan masyarakat muslim saat ini dan pada masa mendatang.

Selain itu, salah satu hal yang sangat memprihatinkan dan menjadi kritik sebagian orang pada era (post) modern ini adalah masalah sistem pendidikan yang terlalu mementingkan pendidikan akademik dan kurang diimbangi dengan kompetensi akhlak (Siradj, 2006). Sehingga, sering kali terlihat melalui media massa bahwa intelektualitas seseorang cukup memadai, tetapi masih melakukan hal-hal yang bertentangan dengan ajaran-ajaran agama dan norma-norma akhlak yang berlaku dalam masyarakat. 
Indonesia sebagai negara yang siap maju, membutuhkan manusia-manusia yang mumpuni. Manusia yang mempunyai kualitas pendidikan yang baik, perilaku yang terpuji serta mempunyai kecerdasan spiritual. Hal ini senada dengan apa yang dinyatakan oleh para pendiri bangsa bahwa ada tiga tantangan besar yang harus dihadapi nation-state Indonesia, yakni pertama, mendirikan Negara yang bersatu dan berdaulat. Kedua, membangun bangsa. Ketiga, membangun karakter (Samani \& Hariyanto, 2012).

Ketiga poin ini tak bisa dipisahkan antara satu dengan lainnya. Membangun negara yang bersatu dan berdaulat tak bisa dipisahkan dengan pembangunan karakter masyarakat Indonesia. Begitu pula dengan membangun bangsa tak bisa dilepaskan dengan membangun karakter masyarakat yang menjadi fondasi menuju nation-state Indonesia yang disegani di belahan dunia manapun. Dalam proses pembentukan karakter tersebut nampaknya telah dimasukkan dalam Undang-undang Sistem Pendidikan Nasional bab II, pasal 2 (dua) tentang Tujuan Pendidikan Nasional yakni mencerdaskan kehidupan bangsa dan mengembangkan manusia Indonesia seutuhnya, yaitu manusia yang beriman dan bertakwa kepada Tuhan Yang Maha Esa dan berbudi pekerti yang luhur, memiliki pengetahuan dan keterampilan, kesehatan jasmani dan rohani, kepribadian yang mantap dan mandiri serta rasa tanggungjawab kemasyarakatan dan kebangsaan (Undang-Undang tentang Sistem Pendidikan Nasional) (Undang-undang tentang sistem pendidikan nasional, 2003).

Membangun karakter dan watak bangsa melalui pendidikan mutlak diperlukan, bahkan tidak bisa ditunda, mulai dari lingkungan rumah tangga, sekolah dan masyarakat dengan meneladani para tokoh yang memang patut untuk dicontoh. Adanya proses kerja sama yang harmonis dari ketiga lembaga tersebut berimplikasi pendidikan akan berjalan dengan baik untuk mencapai tujuan yang dimaksud. Tentunya pendidikan keluarga sebagai pendidikan yang pertama dan utama sebagai basis membangun pendidikan dasar keberagamaan anak.

Salah satu upaya mewujudkannya adalah melalui pendidikan berkarakter. Pendidikan berkarakter diharapkan dapat mengimbangi hasil pendidikan dalam diri peserta didik. Bukankah pendidikan merupakan sebuah proses pengubahan sikap dan tata laku seseorang atau kelompok orang dalam usaha mendewasakan manusia melalui upaya pengajaran dan pelatihan.

Pendidikan karakter adalah pendidikan budi pekerti plus, yaitu yang melibatkan aspek pengetahuan (cognitive), perasaan (feeling), dan tindakan (action). Menurut Thomas Lickona, tanpa ketiga aspek ini, maka pendidikan karakter tidak akan efektif (Lickona, 1999). Pendidikan karakter yang diterapkan secara sistematis dan berkelanjutan, seorang anak akan menjadi cerdas emosinya. Kecerdasan emosi ini adalah bekal penting dalam mempersiapkan anak menyongsong masa depan, karena seseorang akan lebih mudah dan berhasil menghadapi segala macam tantangan kehidupan, termasuk tantangan untuk berhasil secara akademis.

Sebuah penggalan pepatah dari Frank Outlaw mengatakan, “...watch your character, for it becomes your destiny". Jika diterjemahkan, arti pepatah tersebut berbunyi demikian, "Berhati-hatilah dengan karaktermu, karena karaktermu akan menentukan nasibmu." Sadar atau tidak sadar, sesungguhnya apa yang terjadi di dalam hidup seseorang, termasuk diri kita, merupakan buah dari karakter yang melekat pada diri kita (Lickona, 1999).

Karakter merupakan warisan atau bawaan sejak lahir yang tidak dapat diubah menjadi ungkapan yang sering terdengar. Baik buruknya seseorang merupakan warisan 
atau bawaannya sejak lahir sehingga tidak dapat diubah. Pandangan tersebut tentu saja keliru, karena karakter yang dimiliki oleh seseorang bersifat dinamis, tidak statis. Sifat manusia yang dinamis menyebabkan orang yang dulunya jahat menjadi orang yang bersifat baik, dan sebaliknya ada juga orang yang dulunya baik menjadi orang yang memiliki kepribadian jahat. Oleh karena itu, pendidikan karakter berpeluang dalam mengubah karakter dan menyempurnakan diri manusia. Melalui pendidikan karakter, manusia diarahkan dan dibimbing dalam pembentukan karakter yang lebih baik.

Adapun sembilan pilar pendidikan berbasis karakter yang berasal dari nilai-nilai luhur universal, yaitu: pertama, kejujuran (cinta Tuhan dan amanah), kedua, bertanggung jawab (istiqamah, berani, dan menuntut ilmu), ketiga, cinta tanah air (taat aturan, dan adil), keempat, peduli sosial (suka tolong-menolong dan gotong royong/kerjasama), kelima, toleransi (diplomatis, baik, rendah hati, sopan dan penyayang), keenam, disiplin (taat beribadah, cinta baca al-quran, dan taat rukun iman), ketuju, mandiri (kreatif, keatif, dan percaya diri), kedelapan, demokratis (menghargai guru dan orang lain), dan kesembilan gemar membaca (kerja keras) (Muslich, 2013).

Pentingnya pendidikan karakter bagi peserta didik disebabkan karena pendidikan karakter menanamkan nilai-nilai yang berorientasi pada hal positif. Nilai-nilai yang dikembangkan dalam pendidikan karakter bangsa dijelaskan oleh Kementerian Pendidikan Nasional sebagai berikut.

a. Agama

Masyarakat Indonesia merupakan masyarakat beragama. Oleh karena itu, kehidupan individu, masyarakat, dan bangsa selalu didasari pada ajaran agama dan kepercayaannya. Tidak hanya dalam kehidupan sosial, secara politis dalam kehidupan kenegaraan pun didasari pada nilai-nilai yang berasal dari agama. Berdasarkan hal tersebut, nilai-nilai yang didasari pada agama menjadi dasar dalam pendidikan karakter maupun budaya bangsa (Agustian, 2001).

b. Pancasila

Negara kesatuan Republik Indonesia ditegakkan atas prinsip-prinsip kehidupan kebangsaan dan kenegaraan yang disebut Pancasila. Pancasila terdapat pada Pembukaan UUD 1945 dan dijabarkan lebih lanjut dalam pasal-pasal yang terdapat dalam UUD 1945. Artinya, nilai-nilai yang terkandung dalam Pancasila menjadi nilai-nilai yang mengatur kehidupan politik, hukum, ekonomi, kemasyarakatan, budaya, dan seni. Pendidikan budaya dan karakter bangsa bertujuan mempersiapkan peserta didik menjadi warga negara yang lebih baik, yaitu warga negara yang memiliki kemampuan, kemauan, dan menerapkan nilainilai Pancasila dalam kehidupannya sebagai warga Negara (Agustian, 2001).

c. Budaya

Manusia sebagai masyarakat yang hidup di lingkungan dengan nilai-nilai budaya yang telah diakui menjadikan nilai-nilai budaya tersebut sebagai dasar dalam memandang suatu makna dan menjadi arti dalam komunikasi antar anggota masyarakat itu. Budaya sebagai unsur penting dalam masyarakat menjadikan budaya sebagai salah satu sumber nilai pendidikan budaya dan karakter bangsa.

d. Tujuan pendidikan nasional

Tujuan pendidikan menjadi target yang harus dicapai atau dimiliki oleh warga Negara Indonesia dan dikembangkan di berbagai satuan pendidikan tanpa membedabedakan jalurnya. Tujuan pendidikan menunjukkan nilai-nilai kemanusiaan yang harus 
dimiliki warga negara Indonesia. Oleh karena itu, tujuan pendidikan nasional menjadi sumber yang paling operasional dalam pengembangan pendidikan budaya dan karakter bangsa (Agustian, 2001). Tujuan pendidikan menjadi sumber dari pendidikan karakter yang akan diterapkan bagi peserta didik di sekolah. Oleh karena itu, pendidikan karakter tak bisa dipisahkan dari pancasila, nilai agama, nilai budaya, dan tujuan pendidikan nasional. Selain itu, Koesoema menyatakan bahwa pendidikan karakter di sekolah secara sederhana dapat didefinisikan sebagai pemahaman, perawatan, dan pelaksanaan keutamaan (practice of virtue). Pendidikan karakter di sekolah ini mengacu pada proses penanaman nilai, berupa pemahaman-pemahaman, tata cara merawat dan menghidupi nilai-nilai itu, serta menerapkan nilai-nilai tersebut di kehidupan nyata. Pendidikan karakter tidak dipelajari pada suatu mata pelajaran saja, tetapi pendidikan karakter berlangsung selama proses pendidikan dan pembelajaran di sekolah, baik itu visi, misi, maupun kebijakan, pola relasi, dan sebagainya. Pendidikan karakter seakan menjadi ruh dalam setiap proses pendidikan dan pembelajaran yang dilakukan setiap sekolah (Koesoema, 2007).

Pendidikan karakter juga banyak diterapkan di negara lain, semisal Amerika Serikat. Sebuah lembaga yang melakukan penilaian pelaksanaan pendidikan di Amerika Serikat, yaitu character education partnership pada tahun 2006 mengeluarkan laporan mengenai sekolah-sekolah di Amerika Serikat yang mendapat penghargaan sebagai sekolah yang telah berhasil mengembangkan pendidikan karakter yang berjudul 2006 National Schools of Character: Award-Winning Practise. Berdasarkan pengalaman sekolah tersebut dikemukakan ada 11 prinsip pelaksanaan pendidikan karakter, yaitu; (1) Mempromosikan nilai-nilai etika inti; (2) Menentukan "karakter" komprehensif untuk memasukkan berpikir, perasaan, dan perilaku; (3) Mendorong munculnya motivasi diri peserta didik; (4) Kepemimpinan moral dan mengembangkan dukungan jangka panjang bersama; (5) Menciptakan sebuah komunitas sekolah yang peduli; (6) Menyediakan peluang untuk tindakan moral; (7) Memasukkan kurikulum akademik yang bermakna dan menantang; (8) Menggunakan pendekatan komperenshif, disengaja, dan proaktif; (9) Melibatkan staf sekolah sebagai pembelajaran dan komunitas moral; (10) Mengevaluasi inisiatif pendidikan karakter; dan (11) Melibatkan keluarga dan anggota masyarakat sebagai mitra (Beland \& Team, 2006).

Thomas Lickona memiliki pendapat yang berbeda mengenai pendidikan karakter, yakni pertama, kebijaksanaan yang baik. kedua, keadilan menghargai semua orang. ketiga, ketabahan memungkinkan perilaku yang sesuai dengan kesulitan yang dihadapi. keempat, pengendalian diri adalah kemampuan untuk mengatur diri kita sendiri. kelima, kasih sayang melampaui keadilan memberikan yang lebih daripada persyaratan. keenam, sikap positif yang sangat penting. ketujuh, kerja keras yang penuh dengan kesabaran. kedelapan, ketulusan hati melekat kepada prinsip moral, setia kepada nurani moral, menepati janji dan berpegang teguh apa yang kita yakini. kesembilan, berterimakasih sering dilukiskan sebagai rahasia kehidupan. kesepuluh, kerendahan hati sebagai pondasi seluruh kehidupan moral (Octavia dkk., 2014). 


\section{SIMPULAN}

Pada hakikatnya, pendidikan islam dan pembinaan karakter membawa manusia menjadi lebih baik dan senantiasa beritikad baik untuk mengembangkan ilmu pengetahuan dan mengutamakan kepentingan manusia dalam aktivitasnya. Hal ini berarti bahwa pengembangan ilmu pengetahuan dilakukan untuk mensejahterakan manusia dan menjamin kelangsungan hidup berdasarkan norma-norma yang berlaku, baik yang berdasarkan kriteria budaya, politik, sosial, etika kedamaian, maupun ekonomi dalam menciptakan atau mengembangkan intelektual muslim yang berkarakter secara kualitatif. Untuk itu, diperlukan pengadaan kembali ajaran akhlak, moral, dan etika yang sesuai dengan prinsip-prinsip Islam. Melalui pendidikan Islam, kesadaran pribadi peserta didik akan timbul sebagai seorang muslim yang memiliki tanggung jawab terhadap diri sendiri, masyarakat, dan umat. Melalui pendidikan karakter, peserta didik akan menjadi pribadi yang tangguh, bijaksana, arif, dan terbuka. Melalui pendidikan karakter, peserta didik akan terhindar dari karakter dengan sikap mental nihilisme, hedonisme, dan alienasi intelektual.

\section{DAFTAR PUSTAKA}

Achmadi. (2010). Ideologi pendidikan Islam (Cet. II). Yogyakarta: Pustaka Pelajar.

Agustian, A. G. (2001). Rahasia suksess membangun kecerdasan emosi dan spiritual, ESQ (emotional spiritual quotient). Jakarta: Arga.

Andrianto. (2019). Faktor-faktor kenakalan remaja. Jurnal PAI Raden Fatah, 1, 82-104.

Arifin, M. (1991). Ilmu pendidikan Islam suatu tinjauan teoriris dan praktis berdasarkan pendekatan interdisipliner. Jakarta: Bumi Aksara.

Asmuni, Y. (2009). Aliran modern dalam Islam. Surabaya: Al-Ikhlas.

Azra, A. (2006). Pendidikan Islam tradisi dan modernisasi menuju milenium baru (Cet. II). Jakarta: Logos Wacana.

Azzet, A. M. (2011). Urgensi pendidikan karakter di Indonesia: revitalisasi pendidikan karakter terhadap keberhasilan belajar dan kemajuan bangsa. Jakarta: Ar-Ruzz Media.

Beland, K., \& Team. (2006). National school of character: award-winning practise. USA: Character Education Partnership.

Fadjar, A. M. (1993). Pengembangan pendidikan Islam dalam kontekstualisasi ajaran Islam. Jakarta: IPHI \& Paramadina.

Gunawan, H. (2014). Pendidikan karakter: konsep dan implementasi. Bandung: Alfabeta.

Hidayatullah, M. F. (2014). Guru sejati: membangun insan berkarakter kuat dan cerdas (Cet. III). Surakarta: Yuma Pustaka.

Kartawisastra, U. (1980). Strategi klasifikasi nilai (Cet. II). Jakarta: P3R.

Kartono, K., \& Gulo, D. (1987). Kamus psikologi (Cet. I). Bandung: Pionir Jaya.

Kementerian Agama RI. (2003). Al-quran dan terjemahnya (Cet. XVII). Semarang: Thoha Putra.

Koesoema, D. (2007). Pendidikan karakter: strategi mendidik anak di zaman global (Cet. I). Jakarta: Grasindo.

Langgulung, H. (1980). Beberapa pemikiran tentang pendidikan Islam (Cet. I). Bandung: AlMa'arif. 
Lickona, T. (1999). Religion and character education. New York: Phe Delta Kppan.

Megawangi, R. (2004). Pendidikan karakter: solusi yang tepat untuk membangun bangsa. Bogor: Indonesia Heritage Foundation.

Muhaimin. (2008). Nuansa baru pendidikan Islam mengurai benang kusut dunia pendidikan (Cet. I). Jakarta: PT Raja Grafindo Persada.

Muhaimin. (2009). Rekonstruksi pendidikan Islam: dari paradigma pengembangan, manajemen kelembagaan, kurikulum hingga strategi pembelajaran. Jakarta: Raja Grafindo Persada.

Muhaimin. (2011). Pemikiran dan aktualisasi pengembangan pendidikan Islam (Cet. I). Jakarta: PT Raja Grafindo Persada.

Munir, A. (2010). Pendidikan karakter: membangun karakter anak sejak dari rumah. Sleman: Pedagogia.

Muslich, M. (2013). Pendidikan karakter: menjawab tantangan kritis multidimensional (Cet. III). Jakarta: Bumi Aksara.

Nasution, H. (2001). Pembaharuan dalam Islam, sejarah pemikiran dan gerakan (Cet. VII). Jakarta: Bulan Bintang.

Nawanti, S. (2012). Pendidikan karakter. Yogyakarta: Familia.

Octavia, L., Syathibi, I., Ali, M., Gunawan, R., \& Hilmi, A. (2014). Pendidikan karakter berbasis tradisi pesantren. Jakarta: Rumah Kitab \& Norwegian Centre for human Rights.

Poerwadarminta, W. J. S. (2003). Kamus umum bahasa Indonesia (Cet. XI). Jakarta: Balai Pustaka.

Samani, M., \& Hariyanto. (2012). Konsep dan model pendidikan karakter. Jakarta: Rosdakarya.

Siradj, S. A. (2006). Tarbiyah dan kebangsaan: kontribusi kaum santri melampaui eksklusivisme dalam tasawuf sebagai kritik sosial, mengedepankan Islam sebagai inspirasi, bukan aspirasi. Bandung: Mizan.

Sudirman. (2007). Ilmu pendidikan. Bandung: Remaja Rosdakarya.

Suyanto. (2015). Urgensi pendidikan karakter.

Syam, M. N. (1986). Filsafat pendidikan dan dasar filsafat pendidikan pancasila (Cet. I). Surabaya: Usaha Nasional.

Thoha, H. C. (1996). Kapita selekta pendidikan Islam. Yogyakarta: Pustaka Pelajar.

Undang-undang tentang sistem pendidikan nasional. (2003).

Usa, M. (Ed.). (2001). Pendidikan Islam di Indonesia antara cita dan fakta. Yogyakarta: PT. Tiara Wcana Yogya.

Zubaedi. (2012). Desain pendidikan karakter konsepsi dan aplikasinya pada lembaga pendidikan (Cet. II). Jakarta: Kencana. 